Pesq. Vet. Bras. 37(4):331-338, abril 2017 DOI: $10.1590 /$ S0100-736X2017000400006

\title{
Minimum inhibitory concentration of Brazilian Brachyspira hyodysenteriae strains ${ }^{1}$
}

\author{
Amanda G.S. Daniel², José P.H. Sato ${ }^{2}$, Michelle P. Gabardo², Talita P. \\ Resende $^{2}$, David E.S.N. de Barcellos ${ }^{3}$, Carlos E.R. Pereira ${ }^{2}$, Fábio A. Vannucci ${ }^{4,5}$ \\ and Roberto M.C. Guedes ${ }^{2 *}$
}

\begin{abstract}
Daniel A.G.S., Sato J.P.H., Gabardo M.P., Resende T.P., Barcellos D.E.S.N., Pereira C.E.R. Vannucci F.A. \& Guedes R.M.C. 2017. Minimum inhibitory concentration of Brazilian Brachyspira hyodysenteriae strains. Pesquisa Veterinária Brasileira 37(4):331-338. Departamento de Clínica e Cirurgia Veterinária, Escola de Veterinária, Universidade Federal de Minas Gerais, Avenida Pres. Antônio Carlos 6627, Pampulha, Belo Horizonte, MG 31270-901, Brazil. E-mail: guedesufmg@gmail.com

The objectives of this study were to characterize Brachyspira hyodysenteriae isolates and to evaluate the antimicrobial susceptibility patterns of strains obtained from pigs in Brazil based on the minimal inhibitory concentration test (MIC). The MIC was performed for 22 B. hyodysenteriae isolates obtained from 2011 to 2013 using the following antimicrobial drugs: tylosin, tiamulin, valnemulin, doxycycline, lincomycin and tylvalosin. Outbreaks of swine dysentery were diagnosed based on clinical presentation, bacterial isolation, gross and microscopic lesions, duplex PCR for B. hyodysenteriae and B. pilosicoli and nox gene sequencing. All obtained MIC values were consistently higher or equal to the microbiological cut-off described in the literature. The MIC 90 values for the tested drugs were $8 \mu \mathrm{g} / \mathrm{ml}$ for doxycycline, $>4 \mu \mathrm{g} / \mathrm{ml}$ for valnemulin, $8 \mu \mathrm{g} / \mathrm{ml}$ for tiamulin, $32 \mu \mathrm{g} / \mathrm{ml}$ for tylvalosin, $>64 \mu \mathrm{g} /$ $\mathrm{ml}$ for lincomycin and $>128 \mu \mathrm{g} / \mathrm{ml}$ for tylosin. These results largely corroborate those reported in the literature. Tiamulin, doxycycline and tylvalosin showed the lowest MIC results. All of the samples subjected to phylogenetic analysis based on the nox gene sequence exhibited similar results, showing $100 \%$ identity to $B$. hyodysenteriae. This is the first study describing the MIC pattern of $B$. hyodysenteriae isolated in Brazil.
\end{abstract}

INDEX TERMS: Inhibitory concentration, Brachyspira hyodysenteriae, swine dysentery, MIC, diarrhea, antimicrobial sensitivity, nox gene.

RESUMO.- [Concentração inibitória mínima de cepas Brachyspira hyodysenteriae brasileiras.] Os objetivos deste trabalho foram a caracterização de isolados de $\mathrm{Bra}$ chyspira hyodysenteriae e avaliar os padrões de sensibilidade antimicrobiana de isolados obtidos a partir de suínos no

\footnotetext{
${ }^{1}$ Received on June 15, 2016.

Accepted for publication on December 16, 2016.

${ }^{2}$ Departamento de Clínica e Cirurgia Veterinária, Escola de Veterinária, Universidade Federal de Minas Gerais (UFMG), Av. Pres. Antônio Carlos 6627, Pampulha, Belo Horizonte, MG 31270-901, Brazil. *Corresponding author: guedesufmg@gmail.com

${ }^{3}$ Setor de Suínos, Faculdade de Veterinária, Universidade Federal do Rio Grande do Sul (UFRGS), Av. Bento Gonçalves 7712, Agronomia, Porto Alegre, RS 91540-000, Brazil.

${ }^{4}$ Microvet-Microbiologia Veterinária Especial, Rua Joaquim Lopes de Faria 730, João Mariano, Viçosa, MG 36570-000, Brasil.

${ }^{5}$ Veterinary Diagnostic Laboratory, College of Veterinary Medicine, University of Minnesota, Saint Paul, Minnesota, United States of America.
}

Brasil com base no teste de concentração inibitória mínima (MIC). A MIC foi realizada em 22 isolados de B. hyodysenteriae obtidos entre 2011 a 2013 usando os seguintes antimicrobianos: tilosina, tiamulina, valnemulina, doxiciclina, lincomicina e tilvalosina. Surtos de disenteria suína foram diagnosticados com base na apresentação clínica, isolamento bacteriano, lesões macroscópicas e microscópicas, PCR duplex para $B$. hyodysenteriae e $B$. pilosicoli e sequenciamento do gene nox. Todos os valores de MIC obtidos foram consistentemente mais elevados ou igual ao ponto de corte microbiológica descrito na literatura. Os valores de MIC 90 para os fármacos testados foram de $8 \mu \mathrm{g} / \mathrm{mL}$ para a doxiciclina, $>4 \mu \mathrm{g} / \mathrm{ml}$ de valnemulina, $8 \mu \mathrm{g} / \mathrm{mL}$ para a tiamulina, $32 \mu \mathrm{g} / \mathrm{ml}$ para tilvalosina, $>64 \mu \mathrm{g} / \mathrm{ml}$ para a lincomicina e $>128 \mu \mathrm{g} / \mathrm{ml}$ de tilosina. Estes resultados corroboram em grande parte com os relatados na literatura. Tiamulina, doxiciclina e tilvalosina apresentaram os 
menores resultados de MIC. Todas as amostras submetidas à análise filogenética com base na sequência do gene nox exibiram resultados semelhantes, indicando $100 \%$ de identidade com $B$. hyodysenteriae. Este é o primeiro estudo que descreve o padrão MIC de $B$. hyodysenteriae isoladas no Brasil.

TERMOS DE INDEXAÇÃO: Concentração inibitória mínima, Brachyspira hyodysenteriae, disenteria suína, MIC, diarreia, sensibilidade antimicrobiana, sequenciamento do gene nox.

\section{INTRODUCTION}

Brachyspira hyodysenteriae and Brachyspira pilosicoli are the most pathogenic species of spirochetes in grow-finishing pigs (Taylor \& Alexander 1971, Taylor et al. 1980). B. suanatina and B. hampsonii (clades I and II) have also been described as causative agents of swine dysentery (Rasback et al. 2007, Chander et al. 2012), but only B. hyodysenteriae has been described in Brazil. Swine dysentery causes severe mucohaemorrhagic diarrhoea with high morbidity and mortality in untreated animals (Taylor \& Alexander 1971).

Since 2007, an increasing number of cases of swine dysentery have been described, mainly in the United States of America and Canada (Clothier et al. 2011, Chander et al. 2012). In Brazil, between 2010 and 2014, the Veterinary Pathology Laboratory of the Universidade Federal de Minas Gerais (UFMG) diagnosed 18 new swine dysentery outbreaks, which raised concern due to the previous history of only sporadic cases with a low economic impact. In 2012, the major pig-producing region in South Brazil, comprising the three major producing states, reported confirmed cases of swine dysentery. One explanation for this increasing number of swine dysentery cases in many countries is the reduction of bacterial sensitivity to antimicrobial agents that are commonly used for the treatment and control of this disease. The presence of Brachyspira spp. strains with a low response to previously effective antimicrobial agents has been demonstrated in different studies in several countries (Karlsson et al. 2004, Lobová et al. 2004, Duinhof et al. 2008, Pringle et al. 2012). Thus, evaluation of the antimicrobial susceptibility of clinical isolates is essential to obtain a better understanding of this situation.

Despite its clinical importance, no data on the antimicrobial sensitivity of Brazilian $B$. hyodysenteriae strains is available. Thus, eradication and control programmes for swine dysentery in Brazil are being based on the international literature (Guedes 2010).

The objectives of the present study were to isolate and characterize circulating $B$. hyodysenteriae strains in Brazil and to determine the minimal inhibitory concentration (MIC) patterns of these strains.

\section{MATERIALS AND METHODS}

Samples. A total of 30 sections of the large intestine or faeces samples collected from pigs with diarrhoea suspected of having swine dysentery from the states of Rio Grande do Sul, Santa Catarina, São Paulo, Minas Gerais and Mato Grosso were received for diagnosis at the Veterinary Pathology Laboratory of the Veterinary School of the UFMG, between 2012 and 2013. The samples were subjected to histopathology, bacterial isolation, duplex PCR for Brachyspira hyodysenteriae and B. pilosicoli and nox gene sequencing.

Gross and histopathological analysis. The large intestine samples were evaluated for the presence of macroscopic lesions, and fragments were processed via the routine histological technique of dehydration and paraffin embedding. After this procedure, tissue fragments were cut into $3 \mu \mathrm{m}$-thick sections and stained with haematoxylin and eosin (Luna 1968).

Bacterial isolation. The faecal and large intestine samples were subcultured in trypticase soy agar with $5 \%$ sheep blood (TSA) containing $12.5 \mathrm{mg} / \mathrm{l}$ of rifampicin, $200 \mathrm{mg} / \mathrm{l}$ of espectinomicin, $50 \mathrm{mg} / \mathrm{l}$ of vancomicin and $12.5 \mathrm{mg} / \mathrm{l}$ of colistin (Leser et al. 1997), under anaerobic conditions with $\mathrm{N}_{2}(80 \%), \mathrm{CO}_{2}(10 \%)$ and $\mathrm{H}_{2}(10 \%)$, at $42^{\circ} \mathrm{C}$ and examined for growth at 72 and 96 hours. To obtain pure colonies culture, sequential passages in selective medium were performed, and the absence of contaminants was evaluated under phase microscopy.

Duplex PCR for Brachyspira hyodysenteriae and B. pilosicoli. DNA was extracted from faecal samples and mucosal scrapings using a commercial kit PSP ${ }^{\circledR}$ Spin Stool DNA Kit (Invitek, Berlin, Germany). The isolated colonies obtained as described above were also used to extract DNA: following growth on plates, the isolated colonies were washed with $1 \mathrm{ml}$ of sterile PBS for bacterial recovery. The recovered samples were then placed in $1.5 \mathrm{ml}$ microtubes. DNA was extracted from the bacterial colonies via lysis using guanidine thiocyanate, according to Chomczynski (1993).

PCR testing was performed through double amplification targeting the $B$. hyodysenteriae nox gene and the B. pilosicoli 16S RNA gene, according to the protocol described by La et al. (2003). Briefly, the amplification reactions were subjected to an initial step for $5 \mathrm{~min}$ at $95^{\circ} \mathrm{C}$ to activate Taq DNA polymerase, followed by 35 cycles of denaturation at $95^{\circ} \mathrm{C}$ for $30 \mathrm{~s}$, annealing at $52^{\circ} \mathrm{C}$ for $45 \mathrm{~s}$ and extension at $72^{\circ} \mathrm{C}$ for $1 \mathrm{~min}$. The last step consisted of a final extension at $72^{\circ} \mathrm{C}$ for $10 \mathrm{~min}$. The PCR products amplicons were subjected to electrophoresis on a 1\% agarose gel with $1 \mathrm{X}$ TAE buffer, then stained with ethidium bromide and viewed under ultraviolet light.

The primers used were H1 (5'-ACTAAAGATCCTG-ATGTATTTG-3') and H2 (5'-CTAATA-AACGTCTGCTGC-3'), targeting a 354 $\mathrm{bp}$ region of the nox gene of Brachyspira hyodysenteriae, and P1 (5'-AGAGGAAAGTTTTT-TCGCTTC-3') and P2 (5'-GCACCTATGTTAA-ACGTCCTTG-3'), targeting a 823 bp region of the $16 \mathrm{~S}$ segment of B. pilosicoli rRNA.

Nox PCR and sequencing. A total of 30 different isolates, preferably from different herds, were selected for nox gene amplification to identify species belonging to genus Brachyspira and subsequent genomic sequencing, according to Chander et al. (2012). The following primers were used (primer): Brachy nox F 5'-GTT CTT GCG CTG TAA CTC CTC CTA T-3') and Brachy nox R (5'-GCA ACA ATA CCC ATT CTT ACA G -3'), both of which are nox -specific and target a highly variable region of the gene (Atyeo et al. 1999).

The PCR products were purified using the commercial Invitrogen PureLink PCR Purification Kit (Invitrogen, Carlsbad, CA, USA) and sequenced in both directions by a specialized company (BGI Tech Solutions Co., Ltd.) using a Sanger automated sequencer. The obtained sequences were aligned with the sequence alignment programs SeqScape V2.7 and Mega 5.1. The sequence data were presented using a dendrogram, comparing the obtained data with those available in GenBank.

Minimal inhibitory concentration. All of the B. hyodysenteriae strains subjected to the MIC assay were obtained from pure cultures grown previously in blood agar with $5 \%$ ovine blood for 48 hours under an anaerobic atmosphere. To recover bacteria in 
liquid suspensions, the blood agar plates were washed with brain and heart infusion broth (BHI), forming a homogenate with a $10^{6}$ $\mathrm{CFU} / \mathrm{ml}$ final concentration, adjusted via the MacFarland scale.

Antimicrobial susceptibility testing was performed using the broth microdilution method on 22 samples, which represented at least one isolate per herd. The VetMIC ${ }^{\mathrm{TM}}$ Brachy SVA commercial kit was used, which contained the following antimicrobial drugs: tiamulin $(0.063-8 \mu \mathrm{g} / \mathrm{ml})$, valnemulin $(0.031-4 \mu \mathrm{g} / \mathrm{ml})$, doxycycline $(0.125-16 \mu \mathrm{g} / \mathrm{ml})$, tylvalosin $(0.25-32 \mu \mathrm{g} / \mathrm{ml})$, lincomycin $(0.5-64 \mu \mathrm{g} / \mathrm{ml})$ and tylosin $(2-128 \mu \mathrm{g} / \mathrm{ml})$, according to the kit specifications. Each well in the plate kit was inoculated with $0.5 \mathrm{ml}$ of (BHI) supplemented with $10 \%$ foetal bovine serum and approximately $10^{6} \mathrm{CFU} / \mathrm{ml}$ of $B$. hyodysenteriae.

The inoculated plates were incubated in anaerobic atmosphere, under agitation, at $37^{\circ} \mathrm{C}$. The MIC is the lowest concentration that inhibits visible bacterial growth, measured based on the medium turbidity. After four days of incubation, all wells were analysed for possible contaminants that could interfere with the test results. The obtained results were compared with microbiological cut-offs described by Pringle et al. (2012).

Statistical analysis. The MIC results were stratified and summarized considering the median, the mode and the MIC value at which $90 \%$ of the isolates tested were susceptible (MIC 90).

\section{RESULTS}

\section{Gross and histological lesions}

Gross. Fibrinonecrotic colitis was the most frequent lesion associated with abundant mucohemorrhagic contents in the intestinal lumen. In these cases, there was moderate mesocolon oedema and moderate-to-marked hyperaemia of the large intestine. Moderate thickening of the large intestinal wall and watery intestinal contents with a moderate to severe amount of mucus, sometimes associated with blood, were frequently observed. Occasionally, fibrin and a diphtheritic membrane covering the mucosa were also observed.

A difteric membrane was frequently present. In some cases, discrete hyperaemia of the serosa and mild lesions were observed, associated with greenish liquid contents with a moderate amount of mucus. Two animals submitted for a routine survey of enteropathogens from a herd with no history diarrhoea or gross lesions were also evaluated.

Histopathology. The observed histological lesions ranged from multifocal moderate catarrhal colitis to severe necro-hemorhagic neutrophilic colitis combined with goblet cell hyperplasia. Circulatory changes such as congestion and moderate multifocal haemorrhage were commonly found. Superficial erosions associated with multifocal necrosis were also observed in most of the cases. Various degrees of goblet cell hyperplasia, neutrophil infiltration and crypt abscesses were present in all samples. In the lumen of the colon, an amorphous sparingly basophilic material (mucin) was found. In addition, fibrin and cellular debris were visualized. In the large intestinal lumen and the crypts, spiral-shaped bacteria associated with areas of necrosis were often observed.

The large intestinal samples from the two animals that did not have any clinical signs or gross lesions, as described above, exhibited focal mild colonic lesions characterized by superficial necrosis associated with discrete hyperplasia of goblet cells (C7001 and C7003).

\section{Bacterial identification through isolation and duplex PCR}

Beta haemolytic Brachyspira isolates were obtained from all 30 sections of large intestine submitted for diagnosis. These isolates were obtained from 16 herds located in five different Brazilian states from years 2011 to 2013 (Table 1). The bacterial colonies isolated from the received samples exhibited strong beta haemolysis in blood agar and were usually not observed at the agar surface. However, uniform, translucent superficial bacterial growth was occasionally observed spreading from the haemolytic area. Motile bacteria with a spiral morphology were observed under phase contrast microscopy.

All 30 obtained isolates were positive for B. hyodysen-

Table 1. Distribution of Brachyspira hyodysenteriae obtained from 16 swine herds from five differrent Brazilian states from 2011 to 2013

\begin{tabular}{lcccc}
\hline Isolate & States* & Herd & Year & $\begin{array}{c}\text { Number of } \\
\text { samples }\end{array}$ \\
\hline A4441 & MT & 1 & 2011 & 1 \\
A5001, A5002, A50012 & SP & 2 & 2011 & 3 \\
A6002, A6005, A6007, A60011 & MG & 3 & 2011 & 4 \\
B5746, B5747, B57413 & SC & 4 & 2012 & 3 \\
B6731 & SC & 5 & 2012 & 1 \\
B6741 & MG & 6 & 2012 & 1 \\
B7031 & RS & 7 & 2012 & 1 \\
B7201 & SC & 8 & 2012 & 1 \\
B829 & SC & 9 & 2012 & 1 \\
B9001, B9002 & SC & 10 & 2012 & 2 \\
C1526, C1527, C1529 & MG & 11 & 2013 & 3 \\
C3651 & SC & 12 & 2013 & 1 \\
C4941 & SC & 13 & 2013 & 1 \\
C5001 & MG & 14 & 2013 & 1 \\
C6000, C6001, C6013 & MG & 15 & 2013 & 3 \\
C7001, C7002, C7003 & SP & 16 & 2013 & 3
\end{tabular}

*Mato Grosso (MT), Minas Gerais (MG), São Paulo (SP), Santa Catarina (SC) and Rio Grande do Sul (RS).

Table 2. Median, mode value and minimum inhibitory concentration at which $\mathbf{5 0 \%}$ and $\mathbf{9 0 \%}$ (MIC 50, 90) of isolates of $B$. hyodysenteriae are sensitive to each antibiotic teste

\begin{tabular}{lccccc}
\hline Variable & $\begin{array}{c}\text { Median } \\
\mu \mathrm{g} / \mathrm{ml}\end{array}$ & $\begin{array}{c}\text { Mode } \\
\mu \mathrm{g} / \mathrm{ml}\end{array}$ & $\begin{array}{c}\text { Min and Max } \\
\mu \mathrm{g} / \mathrm{ml}\end{array}$ & MIC 50 & MIC90 \\
\hline Tiamulin & 8 & 8 & $0,063->8$ & 8 & 8 \\
Valnemulin & 2 & 4 & $0,031->4$ & 2 & $>4$ \\
Doxicycline & 2 & 2 & $1-8$ & 2 & 8 \\
Tylvalosin & 16 & 32 & $1-32$ & 16 & 32 \\
Lincomycin & 64 & 64 & $2->64$ & 64 & $>64$ \\
Tylosin & $>128$ & $>128$ & $4->128$ & $>128$ & $>128$
\end{tabular}

Table 3. Microbiological cut-off points compared with the values (MIC90) for the isolates in the present study (Pringle et al. 2012)

\begin{tabular}{lcc}
\hline Antimicrobial & MIC90 & Microbiological cut-off point $\$$ \\
\hline Tiamulin & 8 & $>0,25 \mu \mathrm{g} / \mathrm{ml}$ \\
Valnemulin & $>4$ & $>0,125 \mu \mathrm{g} / \mathrm{ml}$ \\
Doxycycline & 8 & $>0,5 \mu \mathrm{g} / \mathrm{ml}$ \\
Tylvalosin & 32 & $>1 \mu \mathrm{ml}$ \\
Lincomycin & $>64$ & $>1 \mu \mathrm{m} / \mathrm{ml}$ \\
Tylosin & $>128$ & $>16 \mu \mathrm{g} / \mathrm{ml}$
\end{tabular}

$\S$ Point of microbiological cut-off is aimed at separating susceptible and resistant isolates compared to wild type. (Pringle et al. 2012). 
teriae and negative for B. pilosicoli via duplex PCR. For isolates C7001, C7002 and C7003, obtained from pigs originated from a herd with no clinical signs of swine dysentery, the positive diagnosis of $B$. hyodysenteriae via duplex PCR was obtained only after bacterial isolation.

\section{Phylogenetic analysis}

Nox sequencing was performed on 30 isolates. Of these isolates, 29 were confirmed as Brachyspira hyodysenteriae, showing $100 \%$ similarity in the 596 base pair segment to the following $B$. hyodysenteriae strains: ATCC 27164, ATCC 3140, AN 2420/97, AN 174/92, AN 383:2/00, AN 1409: 2/01 and B78. A single isolate (C7003) showed divergent results and was identified as Brachyspira murdochii (Fig.1). This sample (C7003) was not included in the MIC test.

\section{Minimal inhibitory concentration}

Twenty-two B. hyodysenteriae isolates, one or two from each herd, were selected and used for the antimicrobial sensitivity test. The MIC values obtained using the six antimicrobial agents in 22 B. hyodysenteriae isolates are shown in Figure 2. Twenty-one isolates exhibited higher MIC values for all active principles than the previously established microbiological cut-off (Pringle et al. 2012). Comparisons between the MIC 90 values and cut-offs are shown in Table 1 and 2.

When the obtained results were compared with the cut-offs described by Pringle et al. (2012) for the wildtype strain (Table 3), the proportion of strains showing low sensitivity was determined to be $90.9 \%$ for tiamulin, $91 \%$ for valnemulin, 95\% for doxycycline, $95 \%$ for tylvalosin, $100 \%$ for lincomycin and $95 \%$ for tylosin.

High MIC values were obtained for tylosin, with one strain falling above the cut-off point (mode $\geq 128$ ). The strains from São Paulo and Minas Gerais were more sensitive than those from Santa Catarina and Mato Grosso, among all tested antimicrobials. Only one isolate from Minas Gerais was sensitive to all of the tested antimicrobials (tiamulin $=0.063 \mu \mathrm{g} / \mathrm{ml} ;$ valnemulin $=0.031 \mu \mathrm{g} / \mathrm{ml} ;$ doxycycline $=$ $0.5 \mu \mathrm{g} / \mathrm{ml}$; tylvalosin $=1 \mu \mathrm{g} / \mathrm{ml}$; lincomycin $=2 \mu \mathrm{g} / \mathrm{ml}$; tylo$\sin =4 \mu \mathrm{g} / \mathrm{ml}$ ), showing similar or lower results compared with the microbiological cut-off proposed by Pringle et al. (2012).

\section{DISCUSSION}

This is the first study to investigate the antimicrobial susceptibility pattern of Brachyspira hyodysenteriae strains isolated from pigs with swine dysentery in Brazil. Although the prevalence of this illness was not determined, it was possible to observe this agent in herds from important Brazilian pig-producing regions (IBGE 2013). Swine herds in these regions are located in highly pig-dense areas, which may increase the likelihood of transmission due to the geographical proximity of the herds and the presence of roads with a high flow of trucks and/or potential vector movement between nearby properties (Hampson et al. 2006).

Atypical behaviour was observed for C7003 compared with the other isolates. Despite showing a positive result for $B$. hyodysenteriae by PCR, this isolate exhibited a high

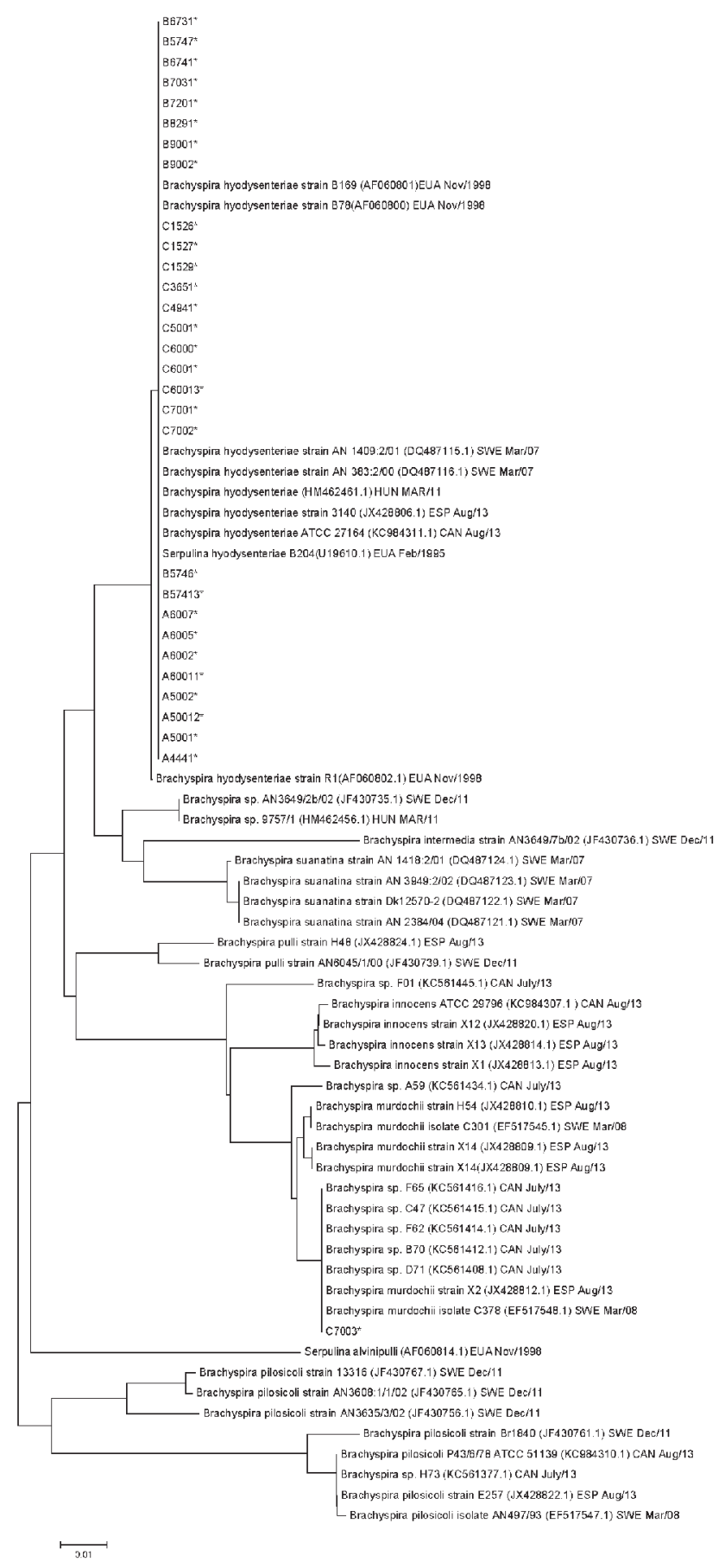

Fig.1. Filogenetic tree based on the NOX gene sequence of a population of 30 Brachyspira sp. isolates aligned (596 bp). The alignment was created using distance calculation (Kimura) and Neighbour-joining. Asterisks represent isolates of the present study.

degree of identity with the species B. murdochii in the phylogenetic analysis. Additionally, milder histological lesions were observed in this case. However, the strong beta haemolysis observed on blood agar and the positive result for B. hyodysenteriae obtained via PCR were intriguing. One possible explanation for these results could be co-culture of the strains $B$. hyodysenteriae and $B$. murdochii in the same blood agar plates, even after multiples passages (Stanton et al. 1997). 
Other isolates (C7001, C7002) from the herd without clinical signs of dysentery was identified according to the nox gene sequence as $B$. hyodysenteriae. There are studies reporting the presence of some atypical low-pathogenicity strains that have the ability to colonize, but not to induce clinical disease (Lysons et al. 1982, Thomson et al. 2001). Further studies are necessary for the characterization of C7001 and C7002 as atypical strain and to clarify the possible impacts caused by this strain when introduced into a naïve herd.

According to the results, there were no differences be-

Tiamulin

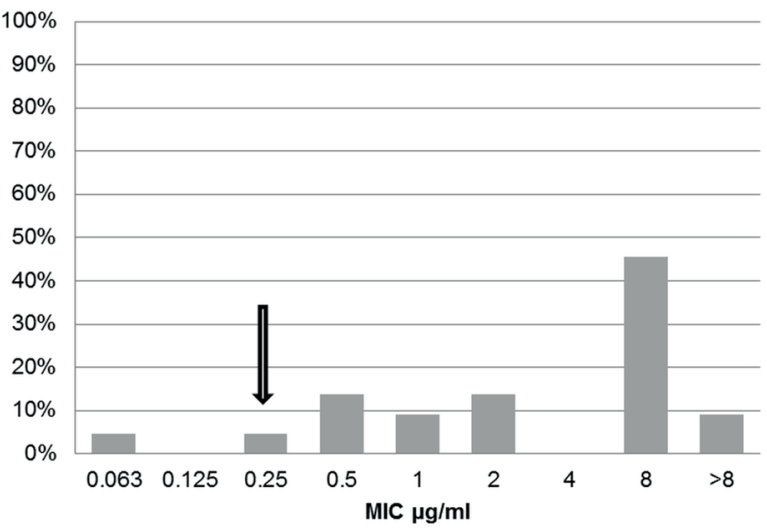

Doxycycline

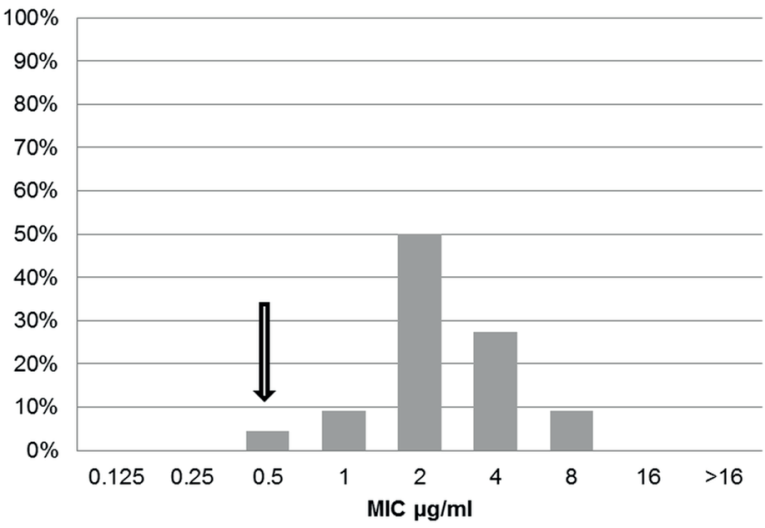

Lincomycin

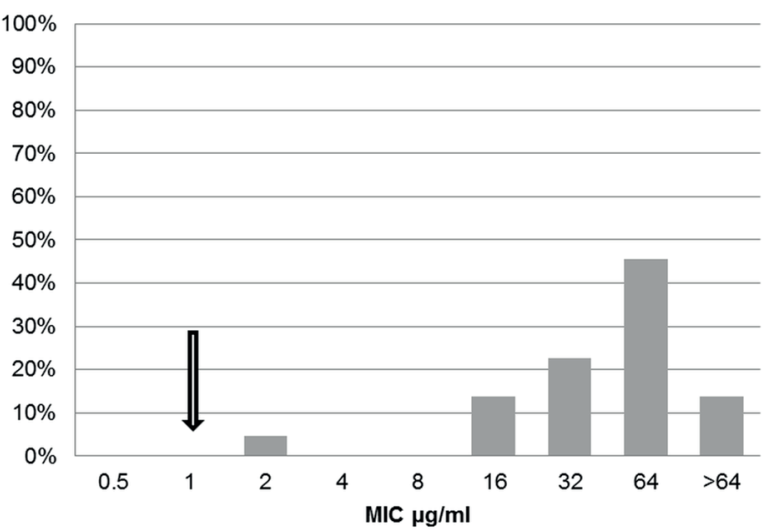

tween the strains isolated in different Brazilian states and herds based on nox gene sequencing before or after the outbreaks in 2012. The sequence of the nox gene is able to differentiate isolates to the species level, but it is not sufficiently discriminatory to differentiate strains within species. Therefore, further studies, using, for example, the multilocus sequence typing (MLST) technique, are required to better understand the epidemiology of the disease in Brazil.

Identifying the sensitivity pattern of Brazilian strains is important for establishing swine dysentery control and eradication programs, mainly due to the emergence of $B$.

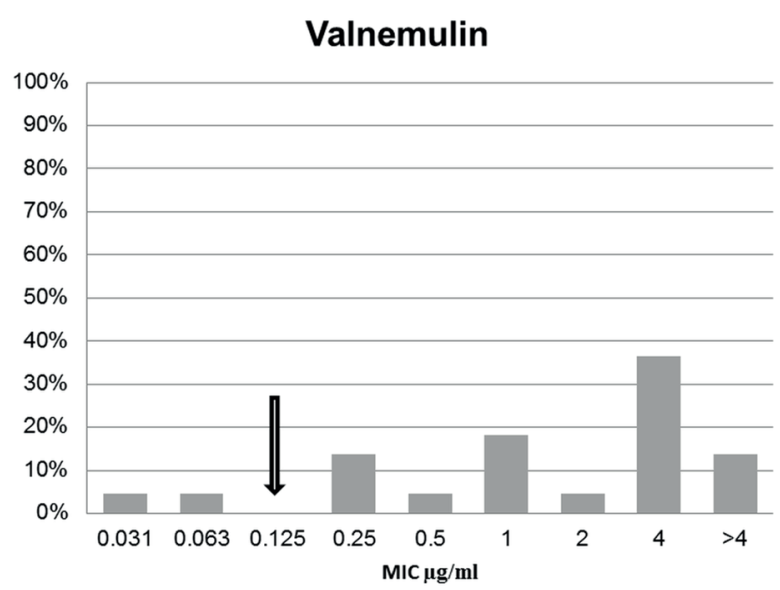

Tylosin

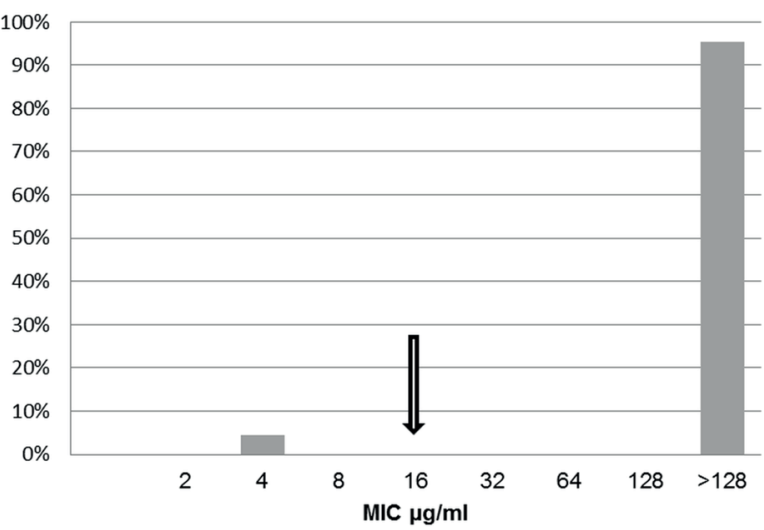

Tylvalosin

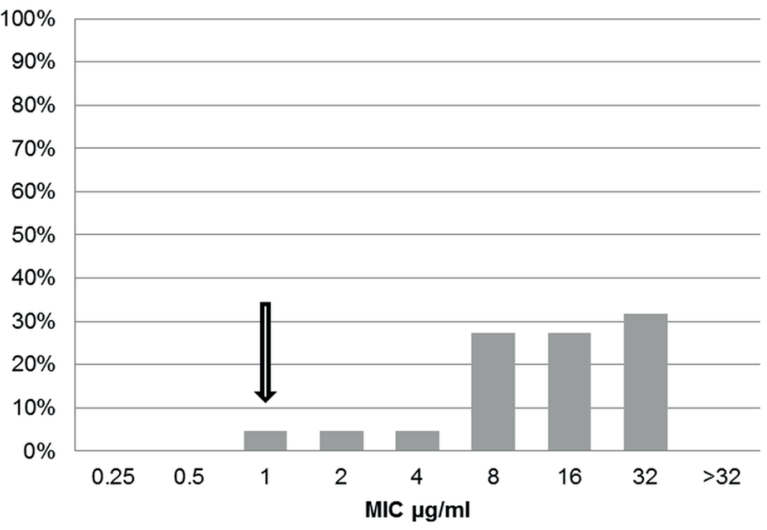

Fig.2. Antimicrobial susceptibility. MIC distribution of six antimicrobial drugs for 22 B. hyodysenteriae isolates in Brazil. The black arrows indicate the cut-off values with respect to the wild type (Pringle et al. 2012). 
hyodysenteriae strains with reduced susceptibility to multiple antimicrobials, based on microbiological cut-off points, which was observed in both the present work and other studies in different countries (Karlsson et al. 2002, 2003, Rohde et al. 2004, Hidalgo et al. 2009, 2011, Zmudzki et al. 2012, Alvarez et al. 2013, Mirajkar \& Gebhart 2013). In addition, low sensitivity is relevant for resistance monitoring programmes as it is an indication of early resistance and allows the implementation of measures to prevent the emergence of strains with high resistance (Pringle et al. 2012).

The MIC results presented here were compared with the literature involving the same broth microdilution technique (Rohde et al. 2004). The results for tylosin were similar to those found in the literature regarding both the MIC50 and MIC90 (Table 1). High resistance to tylosin was expected based on the selective pressure caused by the widespread use of this drug in therapeutic and prophylactic programmes in recent years (Karlsson et al. 2002, 2003, Rohde et al. 2004, Hidalgo et al. 2009, 2011, Zmudzki et al. 2012, Alvarez et al. 2013, Mirajkar \& Gebhart 2013). The mechanism of tylosin resistance is related to mutations in the 23S ribosomal RNA gene at position 2058, inhibiting its binding (Karlsson et al. 1999, 2004).

All of the results obtained for tylvalosin in this study were below the values reported in the literature. Few studies have specifically evaluated the reduction of tylvalosin sensitivity. Hidalgo et al. (2011) identified a mutation in the 23S gene at position 2059 associated with resistance to tylvalosin. For lincomycin, the MIC50 was higher compared with that reported in the literature (Karlsson et al. 1999, Karlsson et al. 2002, Karlsson et al. 2003, Rohde et al. 2004, Hidalgo et al. 2011, Zmudzki et al. 2012, Mirajkar \& Gebhart 2013), however, the MIC 90 was similar to those obtained by Hidalgo et al. (2009) and Alvarez et al. (2013).

For doxycycline, the MIC50 values were comparable to those found by Zmudzki et al. (2012) and Alvarez et al. (2013), but the MIC90 was elevated compared with the previously described values (Karlsson et al. 2002, 2003, Rohde et al. 2004, Pringle et al. 2007, Hidalgo et al. 2009, 2011, Zmudzki et al. 2012, Alvarez et al. 2013, Mirajkar \& Gebhart 2013). Decreased susceptibility to doxycycline has been associated with a mutation at position 1058 of the 16S rRNA gene for $B$. hyodysenteriae (Pringle et al. 2007).

Valnemulin and doxycycline exhibited the lowest MIC values. For valnemulin, the results were similar to those previously reported (Karlsson et al. 1999, 2002, 2003, Rohde et al. 2004, Hidalgo et al. 2009, 2011, Zmudzki et al. 2012, Alvarez et al. 2013, Mirajkar \& Gebhart 2013). The MIC50 results for tiamulin were higher than those published elsewhere, but the MIC90 was similar to the results obtained by Rohde et al. (2004), Hidalgo et al. (2011) and by Alvarez et al. (2013). The resistance related to tiamulin and to the other pleuromutilins is derived from point mutations in the $\mathrm{V}$ domain of the 23S rRNA gene and the ribosomal protein L3 (Hidalgo et al. 2011).

Antimicrobial use is differentially regulated depending on the country. Therefore, the interpretation of MIC results should consider the frequency of drug use and the availability of certain drugs at each location. In countries where carbadox use is allowed, such as the USA, the MIC for tiamulin is low because it is less commonly utilized than in other countries where carbadox is prohibited. This phenomenon is observed in American strains, as demonstrated by Mirajkar \& Gebhart (2013).

Despite the fact that swine dysentery occurs sporadically in Brazilian pig herds, it has increased in relevance since 2010. Therefore, studies are needed to better understand the resistance mechanisms and the correlation between pre-existing strains and those present in recent outbreaks.

Reduced efficacy of these drugs leads to an increased risk of spreading resistant strains and emerging high-pathogenicity clones (Duinhof et al. 2008). Therefore, monitoring the resistance of clinical isolates is highly recommended (Karlsson et al. 2002 \& Rohde et al. 2004).

In recent years, the development of antimicrobial resistance to $B$. hyodysenteriae strains has become a relevant concern. A decrease in susceptibility to tiamulin in different countries has been observed (Karlsson et al. 2004, Lobová et al. 2004, Duinhof et al. 2008, Pringle et al. 2012). Other commonly used drugs, such as lincomycin and tylosin, show high levels of resistance (Hommez et al. 1998, Karlsson et al. 2002). The resistance detected among Brachyspira species is mainly found among $B$. hyodysenteriae strains, but this trend has also been observed for B. pilosicoli (Duhamel et al. 1998, Fossi et al. 1999, Karlsson et al. 2001, 2004, Lobová et al. 2004, Rohde et al. 2004).

Duhamel (2011) suggested two mechanisms for the decreased response to antimicrobials. The first is natural selection of a resistant mutant strain due to constant exposure to antibiotics. The second is horizontal achievement via a bacteriophage known as VSH-1. This bacteriophage is important in gene transfer between its host cells and can contribute to genetic changes in strains through the transduction of new gene sequences between species or Brachyspira strains (Humphrey et al. 1997, Bellgard et al. 2009, Hampson \& Ahmed 2009). These changes may alter phenotypic properties, potentially modifying antimicrobial susceptibility, colonization or virulence (Duhamel 2011).

The use of sub-inhibitory concentrations of antimicrobials is also considered a significant factor under a genetic and evolutionary scenario, as bacterial exposure to subinhibitory concentrations of antimicrobials promotes the activation of mobile components of the bacteria, such as prophages and transposons (Stanton et al. 2008).

\section{CONCLUSIONS}

The MIC results obtained in this study demonstrated resistance to the majority of antimicrobials used against Brachyspira hyodysenteriae, including pronounced resistance to tylosin and lincomycin.

Tiamulin, doxycycline and tylvalosin exhibited better results in comparison with other studies. Epidemiological studies and the use of other molecular techniques will be important for understanding the dynamics of the outbreaks that occurred in 2012 in Brazil.

Future studies involving phenotypic and genotypic characterization of low-pathogenicity $B$. hyodysenteriae strains are needed to evaluate their potential impact in naïve pigs. 
Acknowledgements.- We thank Connie Gebhart at the University of Minnesota Veterinary Diagnostic Laboratory and Dr. Jill Thomson of Scottish Agricultural College for their technical support. We thank Capes, Fapemig and CNPq for financial support. RMC Guedes has a research fellowship from CNPq.

\section{REFERENCES}

Alvarez L.F., Martinez-Lobo J., Aller L.M., Naharro G., Carvajal A. \& Rubio P. 2013. Antimicrobial susceptibility of 78 isolates of Brachyspira hyodysenteriae recovered from swine dysentery outbreaks in Spain during 2011 and 2012. Proc. International Conference on Colonic Spirochaetal Infections in Animals and Humans, Sept. 5-6, UK. 82p.

Atyeo R.F., Stanton T.B., Jensen N.S., Suriyaarachichi D.S. \& Hampson D.J. 1999. Differentiation of Serpulina species b.y NADH oxidase gene (nox) sequence comparisons and nox-based polymerase chain reaction tests. Vet. Microbiol. 67:47-60. doi: 10.1016/s0378-1135(99)00030-9

Bellgard M.I., Wanchanthuek P., La T., Ryan K., Moolhuijzen P., Albertyn Z., Shaban B., Motro Y., Dunn D.S., Schibeci D., Hunter A., Barrero R., Phillips N.D. \& Hampson D.J. 2009. Genome sequence of the pathogenic intestinal spirochete Brachyspira hyodysenteriae reveals adaptations to its lifestyle in the porcine large intestine. PLoS ONE 4:e4641. doi: 10.1371/ journal.pone.000464

Chander Y., Primus A., Oliveira S. \& Gebhart C.J. 2012. Phenotypic and molecular characterization of a novel strongly hemolytic Brachyspira species, provisionally designated "Brachyspira hampsonii". J. Vet. Diagn. Invest. 24:903-910. doi: 10.1177/1040638712456975

Chomczynski P. 1993. A reagent for the single-step simultaneous isolation of RNA, DNA and proteins from cell and tissue samples. Biotechniques 15(3):532-534, 536-537.

Clothier K.A., Kinyon J.M., Frana T.S., Naberhaus N., Bower L., Strait E.L. \& Schwartz K. 2011. Species characterization and minimum inhibitory concentration patterns of Brachyspira species isolates from swine with clinical disease. J. Vet. Diagn. Invest. 23(6):1140-1145. doi: $10.1177 / 1040638711425580$

Duhamel G.E. 2011. Impact of colonic Brachyspira Spirochete host range on transmission of multidrug resistant clinical isolates. Proc. Carlos Pijoan Symposium on Swine Dysentery, Saint Paul, Minnesota, p.1-4.

Duhamel G.E., Kinyon J.M., Mathiesen M.R., Murphy D.P. \& Walter D. 1998. In vitro activity of four antimicrobial agents against North American isolates of porcine Serpulina pilosicoli. J. Vet. Diagn. Invest. 10(4):350-356. doi:10.1177/104063879801000407

Duinhof T.F., Dierikx C.M., Koene M.G., Van Bergen M.A., Mevius D.J., Veldman K.T., Van Beers-Schreurs H.M. \& De Winne R.T. 2008. Multiresistant Brachyspira hyodysenteriae in a Dutch sow herd. Tijdschr. Diergeneeskd. 133(14/15):604-608. doi:10.1016/j.tvjl.2014.02.028

Fossi M., Saranpää T. \& Rautiainen E. 1999. In vitro sensitivity of the swine Brachyspira species to tiamulin in Finland 1995-1997. Acta Vet. Scand. 40(4):355-358.

Guedes R.M.C. 2010. Controle racional das diarreias de recria e terminação. Acta Sci. Vet. 38:247-253.

Hampson D.J., Fellström C. \& Thomson J.R. 2006. Swine dysentery, p.785805. In: Straw B., Zimmerman J., Allaire S. \& Taylor D.J. (Eds), Diseases of Swine. Blackwell, Oxford.

Hampson D.J. \& Ahmed N. 2009. Spirochaetes as intestinal pathogens: lessons from a Brachyspira genome. Gut Pathol. 1(10):1-3. DOI: 10.1186/1757-4749-1-10

Hidalgo A., Carvajal A., García-Feliz C., Osorio J. \& Rubio P. 2009. Antimicrobial susceptibility testing of Spanish field isolates of Brachyspira hyodysenteriae. Res. Vet. Sci. 87(1):7-12. doi: 10.1016/j.rvsc.2008.10.017

Hidalgo A., Carvajal A., Vester B., Pringle M., Naharro G. \& Rubio P. 2011. Trends towards lower antimicrobial susceptibility and characterization of acquired resistance among clinical isolates of Brachyspira hyodysenteriae in Spain. Antimicrob. Agents Chemother. 55(7):3330-3337. doi: 10.1128/AAC.01749-10

Humphrey S.B., Stanton T.B., Jensen N.S. \& Zuerner R.L. 1997. Purification and characterization of VSH-1, a generalized transducing bacteriophage of Serpulina hyodysenteriae. J. Bacteriol. 179(2):323-329.
IBGE 2013. Estatística da Produção Pecuária Setembro de 2012. Diretoria de Pesquisas, Coordenação de Agropecuária, Pesquisa Trimestral do Abate de Animais, 2012/2013. Instituto Brasileiro de Geografia e Estatística, Brasil, p.11-15.

Karlsson M., Fellström C., Heldtander M.U., Johansson K.E. \& Franklin A. 1999. Genetic basis of macrolide and lincosamide resistance in Brachyspira (Serpulina) hyodysenteriae. F.E.M.S. Microbiol. Lett. 172:55-260. doi:10.1016/S0378-1097(99)00047-6

Karlsson M., Gunnarsson A. \& Franklin A. 2001. Susceptibility to pleuromutilins in Brachyspira (Serpulina) hyodysenteriae. Anim. Health Res. Rev. 2:59-65.

Karlsson M., Oxberry S.L. \& Hampson D.J. 2002. Antimicrobial susceptibility testing of Australian isolates of Brachyspira hyodysenteriae using a new broth dilution method. Vet. Microbiol. 84(1/2):123-133.

Karlsson M., Fellström C., Gunnarsson A., Landén A. \& Franklin A. 2003. Antimicrobial susceptibility testing of porcine Brachyspira (Serpulina) species isolates. J. Clin. Microbiol. 41(6):2596-2604. doi: 10.1128/ JCM.41.6.2596-2604.2003

Karlsson M., Aspán A., Landén A. \& Franklin A. 2004. Further characterization of porcine Brachyspira hyodysenteriae isolates with decreased susceptibility to tiamulin. J. Med. Microbiol. 53:281-285. doi:10.1099/ jmm.0.05395-0.

La T., Phillips N.D. \& Hampson D.J. 2003. Development of a Duplex PCR assay for detection of Brachyspira hyodysenteriae and Brachyspira pilosicoli in pig feces. J. Clin. Microbiol. 41(7):3372-3375. doi:10.1128/ JCM.41.7.3372-3375.2003

Leser T.D., Möller K., Jensen T.K. \& Jorsal S.E. 1997. Specific detection of Serpulina hyodysenteriae and potentially pathogenic weakly beta-haemolytic porcine intestinal spirochetes by polymerase chain reaction targeting 23S rDNA. Mol. Cell Probes 11:363-372. doi:10.1006/ mcpr.1997.0129

Lobová D., Smola J. \& Cizek A. 2004. Decreased susceptibility to tiamulin and valnemulin among Czech isolates of Brachyspira hyodysenteriae. J. Med. Microbiol. 53(Pt 4):287-291. doi:10.1099/jmm.0.05407-0

Luna L.G. 1968. Routine Staining Procedures: manual of histologic staining methods of the Armed Forces Institute of Pathology. McGraw-Hill Book Co., New York, p. 24-58.

Lysons R.J., Lemcke R.M., Bew J., Burrows M.R. \& Alexander T.J.L. 1982. An avirulent strain of Treponema hyodysenteriae isolated from herds free of swine dysentery. Proc. 7th International Pig Veterinary Society Congress, July 26-31, Mexico City, Mexico. 40p.

Mirajkar N.S. \& Gebhart C.J. 2013. Antimicrobial Suscebility Patterns of Brachyspira species in U.S. swine herds. Proc. International Conference on Colonic Spirochaetal Infections in Animals and Humans. Sept. 5-6, UK. 53p.

Pringle M., Fellstrom C. \& Johansson K.E. 2007. Decreased susceptibility to doxycycline associated with a 16S rRNA gene mutation in Brachyspira hyodysenteriae. Vet. Microbiol. 123:245-248. doi:10.1186/1751-014754-54

Pringle M., Landén A., Unnerstad H.E., Molander B. \& Bengtsson B. 2012. Antimicrobial susceptibility of porcine Brachyspira hyodysenteriae and Brachyspira pilosicoli isolated in Sweden between 1990 and 2010. Acta Vet. Scand. 54:54. doi:10.1186/1751-0147-54-54

Rasback T., Jansson D.S., Johansson K.E. \& Fellstrom C. 2007. A novel enteropathogenic, strongly haemolytic spirochaete isolated from pig and mallard, provisionally designated 'Brachyspira suanatina' sp. nov. Environ. Microbiol. 9:983-991. doi:10.1111/j.1462-2920.2006.01220.x

Rohde J., Kessler M., Baums C.G. \& Amtsberg G. 2004. Comparison of methods for antimicrobial susceptibility testing and MIC values for pleuromutilin drugs for Brachyspira hyodysenteriae isolated in Germany. Vet. Microbiol. 102:25-32. doi:10.1016/j.vetmic.2004.03.023

Stanton T.B., Fournie-Amazouz E., Postic D., Trott D.J., Grimont P.A, Baranton G., Hampson D.J. \& Saint Girons I. 1997. Recognition of two new species of intestinal spirochetes: Serpulina intermedia sp. nov. and Serpulina murdochii sp. nov. Int. J. Syst. Bacteriol. 47:1007-1012. doi:10.1099/00207713-47-4-1007

Stanton T.B., Humphrey S.B., Sharma V.K. \& Zuerner R.L. 2008. Collateral effects of antibiotics: carbadox and metronidazole induce VSH-1 and fa- 
cilitate gene transfer among Brachyspira hyodysenteriae strains. Appl. Environ. Microbiol. 74(10):2950-2956. doi:10.1128/AEM.00189-08

Taylor D.J. \& Alexander T.J. 1971. The production of dysentery in swine by feeding cultures containing a spirochaete. Brit. Vet. J. 127:58-61.

Taylor D.J., Simmons J.R. \& Laird H.M. 1980. Production of diarrhoea and dysentery in pigs by feeding pure cultures of a spirochaete differing from Treponema hyodysenteriae. Vet. Rec. 106:326-332. doi:10.1136/ vr.106.15.326
Thomson J.R., Smith W.J., Murray B.P., Murray D., Dick J.E. \& Sumption K.J. 2001. Porcine enteric spirochete infections in the UK: surveillance data and preliminary investigation of atypical isolates. Anim. Health Res. Rev. 2:31-36. doi:10.1079/AHRR200123

Zmudzki J., Szczotka A., Nowak A., Strzelecka H., Grzesiak A. \& Pejsak Z. 2012. Antimicrobial susceptibility of Brachyspira hyodysenteriae isolated from 21 Polish farms. Pol. J. Vet. Sci. 15(2):259-265. doi:10.2478/ v10181-011-0143-3 